\section{Child health and nutrition in the Western Brazilian Amazon: population-based surveys in two counties in Acre State}

\author{
Saúde e nutrição infantil na Amazônia Ocidental \\ Brasileira: inquéritos de base populacional em \\ dois municípios acreanos
}

\author{
Pascoal Torres Muniz 1 \\ Teresa Gontijo de Castro ${ }^{2}$ \\ Thiago Santos de Araújo ${ }^{1}$ \\ Nara Barros Nunes 1 \\ Mônica da Silva-Nunes 3 \\ Erika Hellena Esther Hoffmann 3 \\ Marcelo Urbano Ferreira 3 \\ Marly Augusto Cardoso 2
}

\section{Introduction}

Children under five years of age are particularly vulnerable to health problems and constitute a priority target for primary health care. Child health and nutrition are directly related to various factors that are amenable to prevention or modification, like food intake and exposure to various infections 1 . In developing countries, about $36 \%$ of under-five children presented low weight-for-age and $43 \%$ presented low height until the early 1990s 2 , but there is evidence that these prevalence rates have decreased recently in various regions of the world 3 . The prevalence of iron deficiency anemia in the pediatric population in some developing countries can reach $50 \%$, but there are few population-based studies available for comparison 4 .

As in other developing countries 3 , a significant improvement has been observed in child health in Brazil over recent decades, with a nationwide reduction in child mortality and malnutrition ${ }^{5}$. However, since the improvement has been less pronounced in the North and Northeast, preexisting inequalities have been exacerbated between these regions and the Center and South of Brazil 5,6. The most recent available data on the prevalence of child malnutrition in Brazilian counties (or municipalities) are from the 1996 National Demographic and Health Survey (PNDS) 7. Of the 212 under-five children examined in the North, $16.2 \%$ presented low height-
Iron-Deficiency Anemia; Anthropometry; Nutritional Status; Child Welfare 
for-age and $7.7 \%$ low weight-for-age 7 . This situation contrasts with that observed in the South and Southeast, where the prevalence of low height-for-age and low weight-for-age are about $3 \%$ and $6 \%$, respectively 7 .

Adequate planning of child nutrition programs in the North of Brazil requires the availability of recent data from population-based surveys, including information on growth deficits, but also on other nutritional deficiencies. For example, prevalence estimates are scarce for iron deficiency anemia in the Brazilian pediatric population, most of them resulting from the use of inadequate laboratory methods for estimating iron reserves 8 . There are no published data from population-based surveys concerning the prevalence of iron deficiency anemia in Amazonian pediatric populations.

We describe a comprehensive diagnosis of health and nutritional conditions in the pediatric population in two typical Amazonian counties, Acrelândia and Assis Brasil, which differ in terms of the basic economic development model adopted in recent years, but share socioeconomic indicators that are substantially lower than the national average. The county of Acrelândia originated from various nuclei in the Pedro Peixoto Directed Settlement Project, the largest agricultural settlement plan in the State of Acre, implemented by the National Institute for Rural Settlement and Agrarian Reform (INCRA) in the mid-1980s. Acrelândia is a frontier settlement whose adult population consists predominantly of migrants from the Southeast and South of Brazil. Meanwhile, Assis Brasil was incorporated as a county 30 years ago and is inhabited mostly by families from the area itself, working in extractive activities like rubber-tapping and Brazil nut gathering. Part of its territory is located in the Chico Mendes Extractive Reserve, the largest in the State.

\section{Methodology}

\section{Study areas}

The county of Acrelândia, incorporated in 1993, has a territory of $1,607.5 \mathrm{~km}^{2}$, situated between the Abunã and Iquiri (or Ituxi) rivers, in the Acre RiverValley and bordering on Bolivia and the Brazilian States of Amazonas and Rondônia. In this area, described in detail in a previous publication ${ }^{9}$, the University of São Paulo (USP) and the Federal University in Acre (UFAC) have conducted various collaborative surveys on urban and rural health and living conditions 10. Acrelândia is located $112 \mathrm{~km}$ east of Rio Branco, capital of the State of Acre, and has 8,697 inhabitants according to the Brazilian Institute of Geography and Statistics, or National Census Bureau (Instituto Brasileiro de Geografia e Estatística - IBGE) in 2003 11, 43\% of whom in urban areas. The Human Development Index (HDI) was estimated in 2000 at 0.680 , with an infant mortality rate of 70.75 per thousand live births. The functional illiteracy and illiteracy rates are $50.9 \%$ and $26.7 \%$, respectively 12,13 . The main economic activity is commercial agriculture.

Assis Brasil, incorporated in 1976, has a population of 3,667 (IBGE estimate for 2003 9), 62\% in the urban area. Assis Brasil has a territory of $2,884.2 \mathrm{~km}^{2}$, located on the border with Bolivia and Peru and the counties of Brasiléia and Sena Madureira in Acre State, and is located $344 \mathrm{~km}$ southwest of Rio Branco. The overall HDI in 2000 was 0.670 , with an infant mortality rate of 67.4 per thousand live births. The functional illiteracy and illiteracy rates are $51.3 \%$ and $29 \%$, respectively 12,13 . The main economic activities are cattle raising and timbering, with an insignificant agricultural crop output.

\section{Study population, data collection, and ethical aspects}

We conducted a cross-sectional study of the entire population under five years of age residing in the urban area of Acrelândia and Assis Brasil. Data and samples (interviews, anthropometry, and blood and stool samples for laboratory tests) were collected from January 14 to 31 , 2003, during the rainy season of the Western Amazon. All 491 households were visited (334 in Acrelândia and 157 in Assis Brasil) in which the total of 724 under-five children lived, according to records from the Family Health Program, updated in December 2002. The fieldwork was done with the participation of community health agents, nursing students from UFAC, and universitylevel health professionals with training and local supervision by the project research team. During the home visits, the interviewers introduced themselves, explained the survey's objectives and benefits, and asked the parents or guardians to sign a free informed consent form, ensuring them of the confidentiality of the resulting information and feedback with the individual results of laboratory tests. The study was reviewed and approved by the Institutional Review Board of the School of Public Health, University of São Paulo (USP research protocol no. 810). 
Description of socioeconomic conditions and disease history

During the fieldwork, two supervisors distributed the structured questionnaires to the interviewers, to be applied to the children's parents or guardians in home interviews in order to obtain data on socioeconomic and environmental variables. The target variables were: (a) demographic (child's gender and age); (b) socioeconomic (presence of home appliances and consumer goods in the household, paternal schooling, presence of the father in the household, maternal work, number of members currently living in the household), and environmental (connection to the public sewage system and water supply, garbage collection); (c) reproductive (maternal age, gestational age and birth weight); (d) nutritional (total and exclusive breastfeeding and weaning foods); (e) past morbidity (diarrhea, cough, or fever in the 15 days prior to the home visit, bouts of malaria in the previous 12 months, hospitalization of the child and wheezing in the previous 12 months).

\section{Anthropometric evaluation}

A single observer (T.G.C.) measured the child's weight and stature, and the mean of two separate measurements was used for the data analysis. Children two years or older were weighed with a portable electronic digital scale (Plenna, USA), with a capacity of $150 \mathrm{~kg}$ and accurate to $100 \mathrm{~g}$. Children under two years of age were weighed using a digital pediatric scale with a capacity of $16 \mathrm{~kg}$ and accurate to $10 \mathrm{~g}$ (Soehnle, Germany). Children two years or older were measured with a stadiometer, accurate to $0.1 \mathrm{~cm}$, attached to a flat surface on a wall without a baseboard and perpendicular to the floor. The children were positioned barefoot in the vertical standing position in the middle of the stadiometer, with the head, shoulders, buttocks, and heels leaning against the wall. Children under two years of age were measured with an infant anthropometer, accurate to $0.1 \mathrm{~cm}$. This measurement required two observers (P.T.M. and T.G.C.), placing the child in the supine position on the anthropometer, set on a table. The child's head was placed vertically and in contact with the upper base of the equipment, with the legs extended. Weight-for-age (W/A), weightfor-height $(\mathrm{W} / \mathrm{H})$, and height-for-age $(\mathrm{H} / \mathrm{A})$ were calculated as z-scores, using Epi Info version 6.01 (Centers for Disease Control and Prevention, Atlanta, USA), based on the reference population of the National Center for Health Statistics (NCHS) for 1977 14. Children were defined as malnourished with W/A, W/H, or H/A less than or equal to $-2 \mathrm{z}$-scores. Children were defined as overweight with $\mathrm{W} / \mathrm{H}$ greater than or equal to $+2 \mathrm{z}$-scores. Parents of children with abnormal nutritional parameters were oriented to take them to the local unit of the Family Health Program.

\section{Diagnosis of intestinal parasites}

A stool sample was requested from all the study subjects at the time of the interview, for subsequent analysis, and Coprotest $₫$ cups containing a preservative solution ( $10 \%$ formalin) were provided for this purpose. The stool samples were examined as described by Hoffman et al. 15, in laboratories installed in the two counties. The parasitological diagnostic method used is appropriate for detecting the eggs and cysts of most human intestinal parasites, except for Cryptosporidium parvum, Cryptosporidium hominis, and Cyclospora cayetanensis cysts, Enterobius vermicularis eggs, and Strongyloides stercoralis larvae. The maximum time elapsed between collecting and processing stool samples was two weeks. Individuals with intestinal parasitic infections received free treatment 16 , prescribed by the project's medical team.

\section{Diagnosis of anemia and iron deficiency}

Venous blood samples, drawn after 10-12 hours of fasting, were used to measure blood hemoglobin with a Hemocue portable hemoglobinometer (Ängelhom, Sweden). Anemia was defined as values below the cutoff point of $11.0 \mathrm{~g} / 100 \mathrm{ml}$ of blood, set by the World Health Organization (WHO) 17. Body iron status were assessed in two stages. Initially the plasma ferritin levels were determined, and iron deficiency was defined as less than $12 \mu \mathrm{g} / \mathrm{L} 17$. In children with plasma ferritin levels above the stipulated cutoff point, a second test was used: determination of plasma soluble transferrin levels. This strategy aimed to diagnose iron deficiency in children with inflammatory or infectious processes, which tend to increase the ferritin levels without altering the soluble transferrin levels 17 . Both were measured using enzyme-linked immunosorbent assay (ELISA) with commercially available reagents (Ramco Laboratories, Stafford, USA). Since there is no consensus as to the cutoff for diagnosis of iron deficiency based on plasma soluble transferrin levels 17, the cutoff suggested by the kit manufacturer was used $(8.3 \mathrm{mg} / \mathrm{L})$. Children with anemia diagnosed during the study received free treatment with ferrous sulfate ( $2 \mathrm{mg}$ of iron per $\mathrm{kg}$ body weight for children under two years of age and $4 \mathrm{mg}$ of iron per kg weight for other ages), prescribed by the research project's medical team. 


\section{Data processing and analysis}

The collected data were keyed in and analyzed using SPSS PC+ version 12.0 (SPSS Inc., Chicago, USA). Relative and absolute frequency distributions, medians, means, and standard deviations of the variables were calculated. Statistical analysis used the Student $t$ test for independent samples and the chi-square for comparison of means and proportions, respectively. Statistical significance was set at $\mathrm{p}<0.05$.

The families' socioeconomic status was evaluated by calculating a wealth index based on the presence of consumer goods and home appliances in the household 18 . The family income variable was not used in this analysis because it is difficult information to obtain and provides an imprecise reflection of household socioeconomic status 18 . The family wealth index was obtained by principal components analysis using XLSTAT software, version 7.5.2 (Addinsoft, New York, USA). The first principal component, which explained $32.7 \%$ of the variation among families, was used to derive weights (in parentheses) for each asset present in the household: television set $(0.264)$, stereo system $(0.280)$, VCR $(0.135)$, stove $(0.200)$, refrigerator $(0.311)$, radio $(0.203)$, telephone (0.278), blender (0.345), bicycle $(0.217)$, electric iron (0.307), motor vehicle $(0.161)$, sofa $(0.312)$, washing machine (0.327), and satellite antenna (0.295). After standardizing the weights assigned to the consumer items, the highest (positive) scores were associated with the presence of a motor vehicle (2.835), VCR (2.865), telephone (1.350), radio (1.242), satellite antenna (1.161), and sofa (1.039), and the lowest (negative) scores with the absence of a stove (-4.141), refrigerator (-1.876), television set (-1.833), bicycle (-1.446), blender $(-1.303)$, washing machine $(-1.292)$, stereo system $(-1.060)$, and electric iron $(-1.275)$ in the household. The scores were all added to produce an estimated index of household wealth, which was then categorized in quartiles. Prevalence rates for nutritional disorders were analyzed according to wealth index quartile.

\section{Results}

Demographic, socioeconomic, and environmental characteristics

Of the 724 children identified in the household survey, 720 (99.4\%) were interviewed; only four children were not interviewed because their parents or guardians refused to provide consent. In all, the sample population included 677 subjects who completed the physical and clinical exami- nation (93.5\% of the eligible individuals). In Assis Brasil, the mean age of the study population was 29.5 (SD 16.9) months, and $48 \%$ of the children were males. In Acrelândia, the mean age was 31.42 (SD 16.9) months, with $49.5 \%$ males. The majority of families in both counties did not own their land; there were significantly more landowners in Assis Brasil (27.5\%) than in Acrelândia (18.4\%) $(\mathrm{p}=0.027)$.

Table 1 shows the sample population's demographic characteristics and household socioeconomic and environmental variables for the two counties. Although paternal schooling was lower in Acrelândia, mean schooling was low in both counties (7.1 years in Assis Brasil and 6.2 years in Acrelândia; Student t test, $\mathrm{p}<0.05$ ). In both counties the majority of the households had toilets, but few households were connected to the public sewage system (3\% in Assis Brasil and $1.5 \%$ in Acrelândia), and human waste was generally dumped into septic tanks or sewage tanks. Acrelândia had lower proportions of households with running water and sewage connections. The majority of households in both counties disposed of garbage adequately (garbage collection, public dumpsters, or garbage buried or burned).

\section{Reproductive, birth weight, and breastfeeding characteristics}

In both counties, the majority of mothers worked at home, with a higher proportion of mothers who worked outside the home in Assis Brasil (23\%) than in Acrelândia ( $11.7 \%)(p=0.023)$. The reported prematurity rate was low: $2.5 \%$ in Assis Brasil and $2.7 \%$ in Acrelândia. The prevalence of low birth weight $(<2,500 \mathrm{~g})$, based on information from the children's health cards, was higher in Acrelândia (9.6\%) than in Assis Brasil (4.5\%) (p = $0.025)$. Mean maternal age (SD) was similar in the two counties: 26.3 years (SD 7.5) in Assis Brasil and 27.1 years (SD 8.9) in Acrelândia.

In the entire study population, $94.1 \%$ of infants $(n=634)$ started breastfeeding, with no statistically significant difference between the two counties (92\% in Assis Brasil and $94.7 \%$ in Acrelândia). Overall, $30 \%$ of infants showed exclusive breastfeeding up to six months (not including those who never breastfed). Nine percent of children $(n=43)$ breastfed for at least two years, and there was a median of 180 days of total breastfeeding.

\section{Nutritional status}

The overall nutritional deficiency prevalence rates according to the $\mathrm{W} / \mathrm{H}, \mathrm{W} / \mathrm{A}$, and $\mathrm{H} / \mathrm{A}$ indices were $3.7 \%, 8.7 \%$, and $7.5 \%$, respectively. The 
Frequency distribution of demographic, socioeconomic, and environmental variables in two counties of Acre State, Brazil, 2003

\begin{tabular}{|c|c|c|c|c|}
\hline \multirow[t]{2}{*}{ Socioeconomic variables } & \multicolumn{2}{|c|}{ Assis Brasil $(n=200)$} & \multicolumn{2}{|c|}{ Acrelândia $(n=477)$} \\
\hline & $\mathbf{n}$ & $\%$ & n & $\%$ \\
\hline \multicolumn{5}{|l|}{ Gender } \\
\hline Male & 96 & 48.0 & 236 & 49.8 \\
\hline Female & 104 & 52.0 & 238 & 50.2 \\
\hline \multicolumn{5}{|l|}{ Age bracket (months) * } \\
\hline $0-5$ & 20 & 10.0 & 53 & 11.2 \\
\hline $6-11$ & 42 & 21.0 & 85 & 17.9 \\
\hline $12-23$ & 43 & 21.5 & 101 & 21.3 \\
\hline $24-59$ & 95 & 47.5 & 235 & 49.6 \\
\hline \multicolumn{5}{|l|}{ Inhabitants per household ** } \\
\hline$\leq 3$ & 33 & 16.6 & 54 & 11.6 \\
\hline $4-6$ & 108 & 54.3 & 299 & 64.3 \\
\hline $7-10$ & 58 & 29.1 & 112 & 24.1 \\
\hline \multicolumn{5}{|l|}{ Paternal schooling (years) ** } \\
\hline None & 15 & 8.2 & 47 & 11.4 \\
\hline $1-4$ & 50 & 27.5 & 157 & 38.1 \\
\hline $5-8$ & 39 & 21.4 & 128 & 31.1 \\
\hline$>8$ & 78 & 42.9 & 80 & 19.4 \\
\hline \multicolumn{5}{|l|}{ Drinking water ** } \\
\hline Public water supply & 154 & 77.0 & 254 & 53.2 \\
\hline Artesian well & 42 & 21.0 & 216 & 46.8 \\
\hline \multicolumn{5}{|l|}{ Garbage } \\
\hline Public garbage collection & 178 & 89.0 & 364 & 76.3 \\
\hline \multicolumn{5}{|l|}{ Sewage disposal } \\
\hline Septic tank & 138 & 69.7 & 360 & 76.9 \\
\hline
\end{tabular}

* In Acrelândia, $n=474$, since the birth dates were not available for three children;

** Comparison of the two counties using the $\chi^{2}$ test, $p<0.05$.

prevalence of $\mathrm{W} / \mathrm{H}$ and $\mathrm{H} / \mathrm{A}$ deficits increased significantly with age beginning at 12 months $\left(\chi^{2}\right.$ test for trend, $\mathrm{p}<0.001)$. No statistically significant differences were observed between counties in malnutrition prevalence rates $\left(\chi^{2}=0.45, \mathrm{p}=\right.$ $0.50 ; \chi^{2}=0.07, \mathrm{p}=0.79 ; \chi^{2}=0.28, \mathrm{p}=0.59$, respectively for W/A, W/H, and H/A) or overweight $\left(\chi^{2}=\right.$ $0.16, p=0.70)$. Overall overweight prevalence according to the $\mathrm{W} / \mathrm{H}$ index was $2.8 \%$, with no statistically significant difference by gender. However, overweight prevalence tended to decrease with age $\left(\chi^{2}=6.05, \mathrm{p}=0.014\right)$, with the highest prevalence of overweight in the 12 to 24 -month age group (7\%).

We measured hemoglobin concentration in 669 children $(92.4 \%$ of the eligible children and $98.8 \%$ of those interviewed and examined) and plasma ferritin in 628 (86.7\% of the eligible children and $92.8 \%$ of those interviewed and examined). Plasma transferrin receptor levels were measured in the 326 children who presented normal or elevated plasma ferritin. Based on hemoglobin levels, 205 children (30.6\%) were classified as anemic. Based on the combined analysis of plasma ferritin and transferrin receptor levels, 273 children $(43.5 \%)$ were classified as iron deficient. Combining the results for hemoglobin, ferritin, and soluble transferrin receptor, 130 children $(20.9 \%)$ were diagnosed with iron deficiency anemia. There were no statistically significant differences in the prevalence rates for anemia, iron deficiency, and iron deficiency anemia according to gender or county. In all, $68.1 \%$ of the anemic children presented iron deficiency, while the remaining cases of anemia were attributed to other nutritional deficiencies or various other etiological factors. Only $47.6 \%$ of the children with iron deficiency presented anemia, highlighting the low sensitivity of hemoglobin measurement to diagnose iron deficiency at the population level. 
Statistically significant differences were observed in the anemia, iron deficiency, and iron deficiency anemia rates according to age; the highest prevalence rates for anemia (50.2\%), iron deficiency (62\%), and iron deficiency anemia (38.9\%) were observed in children under 24 months of age, as compared to the other age groups ( $\chi^{2}$ test, $\mathrm{p}<0.0001$ ).

Table 2 shows the frequency of nutritional deficits in each municipality. There were no statistically significant differences between counties

\section{Table 2}

Frequency distribution of nutritional deficiencies based on low W/A (weight/age), $\mathrm{H} / \mathrm{A}$ (height/age), W/H (weight/height), overweight according to high $\mathrm{W} / \mathrm{H}$, iron deficiency, and iron deficiency anemia in two counties of Acre State, Brazil, 2003.

\begin{tabular}{|c|c|c|c|c|}
\hline \multirow[t]{2}{*}{ Nutritional disorders } & \multicolumn{2}{|c|}{ Assis Brasil $(n=200)$} & \multicolumn{2}{|c|}{ Acrelândia ( $n=477)$} \\
\hline & $\mathrm{n}$ & $\%$ & $\mathbf{n}$ & $\%$ \\
\hline \multicolumn{5}{|l|}{ Malnutrition * } \\
\hline W/A index & 15 & 7.5 & 44 & 9.3 \\
\hline $\mathrm{H} / \mathrm{A}$ index & 13 & 6.5 & 37 & 7.8 \\
\hline W/H index & 8 & 4.0 & 17 & 3.6 \\
\hline Overweight ** & 4 & 2.0 & 15 & 3.2 \\
\hline Anemia $\star \star \star$ & 70 & 36.3 & 135 & 24.5 \#\#\# \\
\hline Iron deficiency \# & 85 & 45.2 & 188 & 42.7 \\
\hline Iron deficiency anemia \#\# & 48 & 26.4 & 82 & $18.7 \# \# \#$ \\
\hline
\end{tabular}

* Two or more standard deviations below the standard median of the National Center for Health Statistics $14 ; n=474$ in Acrelândia;

** Two or more standard deviations above the standard median of the National Center for Health Statistics 14; $\mathrm{n}=474$ in Acrelândia;

$\star \star \star$ Blood hemoglobin less than $11 \mathrm{~g} / \mathrm{dL}$;

\# Plasma ferritin $<12 \mu \mathrm{g} / \mathrm{L}$ or transferrin receptor $>8.3 \mathrm{mg} / \mathrm{L}$;

\#\# Blood hemoglobin less than $11 \mathrm{~g} / \mathrm{dL}$ and plasma ferritin $<12 \mu \mathrm{g} / \mathrm{L}$ or transferrin receptor $>8.3 \mathrm{mg} / \mathrm{L}$;

\#\#\# $\chi^{2}$ test, $p<0.05$.

\section{Table 3}

Frequency distribution of intestinal parasitic infections and reported

diseases in two counties of Acre State, Brazil, 2003.

\begin{tabular}{|c|c|c|c|c|}
\hline \multirow[t]{2}{*}{ Disease } & \multicolumn{2}{|c|}{ Assis Brasil $(n=200)$} & \multicolumn{2}{|c|}{ Acrelândia $(n=477)$} \\
\hline & $\mathbf{n}$ & $\%$ & $\mathbf{n}$ & $\%$ \\
\hline Intestinal parasites & 51 & 31.7 & 127 & 32.4 \\
\hline Diarrhea in the previous 15 days & 69 & 34.5 & 129 & 27.2 \\
\hline Any lifetime hospitalization * & 38 & 19.0 & 131 & 27.5 \\
\hline Cough or fever in the previous 15 days & 77 & 38.5 & 157 & 33.3 \\
\hline Wheezing the previous 12 months & 43 & 21.5 & 93 & 19.7 \\
\hline
\end{tabular}

* $\chi^{2}$ test, $p<0.05$. in the prevalence rates for malnutrition or obesity. However, the prevalence rates for anemia and iron deficiency anemia were significantly higher in Assis Brasil.

\section{Reported diseases and \\ intestinal parasites}

Of the 554 children who had stool samples obtained and examined $76.5 \%$ of the eligible children and $81.8 \%$ of those interviewed and examined), 180 (32.5\%) harbored one or more intestinal protozoa or helminths detected by the parasitological method used in the study. No statistically significant difference was observed in the prevalence of intestinal parasites comparing boys $(26.6 \%)$ and girls $(27.5 \%)$ or children from Assis Brasil (31.7\%) and Acrelândia (32.4\%).

The most common infections involved the protozoan parasite Giardia duodenalis (18\% in Assis Brasil, $\mathrm{n}=29$; and $27.7 \%$ in Acrelândia, $\mathrm{n}=109)$, the commensal protozoan Entamoeba coli (6.2\% in Assis Brasil, $\mathrm{n}=10$; and $5.1 \%$ in Acrelândia, $\mathrm{n}=20)$, and the helminth Ascaris lumbricoides (9.9\% in Assis Brasil, $\mathrm{n}=16$; but only $0.2 \%$ in Acrelândia, $n=1$ ). Multiple parasite infections (simultaneous infection with two or more species of intestinal parasites or commensals) were observed in $6.8 \%$ of the children examined in Assis Brasil and $4.1 \%$ of those in Acrelândia. Combining the data from the two counties, the prevalence of intestinal parasites increased significantly with age ( $\chi^{2}$ test for trend, $\mathrm{p}<0.00001)$.

Table 3 shows the prevalence distribution of intestinal parasites and reported disease events in the two counties. There were a higher proportion of children with a history of hospitalization in Acrelândia than in Assis Brasil, but no statistically significant differences were seen between the counties in the prevalence of other reported disease events. Only six children (1.2\%) in Acrelândia (and one in Assis Brasil) had one or more episodes of malaria diagnosed in the 12 months prior to the survey.

\section{Prevalence of malnutrition and anemia according to household wealth index}

Figure 1 shows the association between the wealth index and the overall malnutrition prevalence rates according to the H/A index and anemia in the combined pediatric population of Assis Brasil and Acrelândia $(n=674)$. There was a statistically significant inverse association between prevalence of both malnutrition and anemia and household wealth index ( $\chi^{2}$ test for trend, $p=0.006$ and $p=0.0005$, respectively). No 


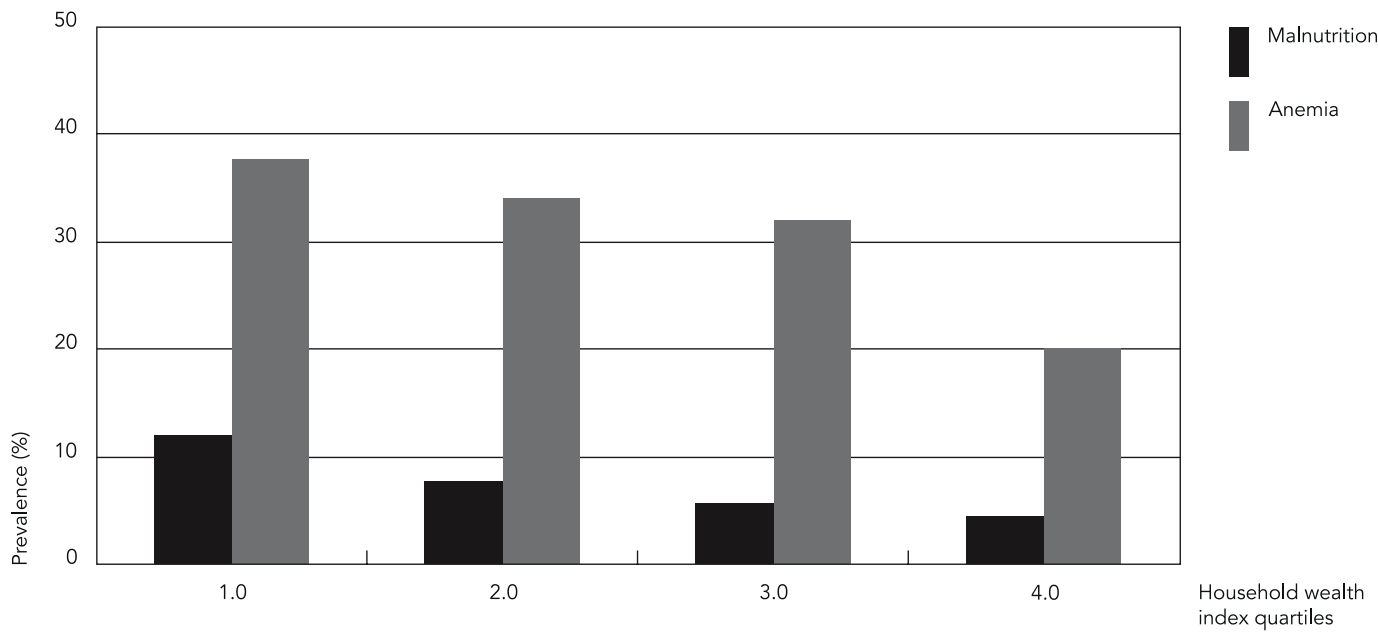

Statistically significant inverse association between prevalence of malnutrition/anemia and household wealth index: $\chi^{2}$ tendency test, $p=0.006$ and $p=0.0005$, respectively.

association was observed between household wealth index and intestinal parasites prevalence.

\section{Discussion}

Although Acrelândia and Assis Brasil are examples of Amazonian counties with distinct economic activities, they show very similar childhood health indicators. The results of this study only showed significant differences between the counties in the prevalence rates for anemia and iron deficiency anemia, which were more common in Assis Brasil than in Acrelândia (Table 2). In both counties, the prevalence of growth deficit (according to the height-for-age index) was nearly $50 \%$ lower than that observed in 212 children from the North of Brazil examined during the PNDS in 1996 (16.2\%) 7. The prevalence of low weight-for-age in both counties $(8.7 \%)$ was similar to that observed in the PNDS (7.7\%), while the prevalence of low weight-for-height in Assis Brasil and Acrelândia (3.7\%) was three times higher than the PNDS figure for the North of Brazil (1.2\%) 7. Surprisingly, the prevalence of low weight-for-height in children from the North examined by the PNDS was the second lowest in
Brazil, slightly more than half the national average of $2.3 \% 7$. Since no time series are available for analysis, it is not known whether the discrepancies between the estimates in our study and those of the PNDS are due to spatial heterogeneities in the Northern Region or simply reflect a trend towards preferential improvement in some child health and nutrition indicators over the course of the last decade

The lack of prevalence estimates for iron deficiency anemia in Brazilian pediatric populations makes comparisons difficult. Most available studies are based on convenience samples (health services users, for example), submitted exclusively to hemoglobin testing ${ }^{8}$, failing to provide data on body iron status 19 . The current study provides the first estimates derived from population-based surveys of the prevalence of iron deficiency anemia in children from the Brazilian Amazon. Two results are particularly relevant for the prevention and control of anemia in this population: (a) only $47.6 \%$ of the children with iron deficiency had anemia, indicating that measuring hemoglobin alone underestimates the magnitude of iron deficiency in this population by more than $50 \%$ and (b) $31.9 \%$ of anemic children had no biochemical evidence of iron deficiency, suggesting the role of other determi- 
nants of anemia (nutritional, biochemical, or infectious) in this population.

The proportion of anemic children in our sample (30.6\%) was similar to that found in preschoolers in Paraíba State (36.4\%) 20, but lower than observed in the same age bracket in recent population-based surveys in the State of Pernambuco $(40.9 \%) 21$ and in counties of São Paulo State $(46.9 \%)$ 22, Criciúma, Santa Catarina State (54\%) 23, and Porto Alegre, Rio Grande do Sul State $(47.8 \%) 24$. The available data suggest that the highest pediatric anemia prevalence rates occur in urban areas of the most developed regions of the country. However, some factors limit the validity of these comparisons: (a) several estimates are from studies with blood samples drawn by finger-prick, a procedure that can dilute the sample and introduce a systematic error into hemoglobin measurement 25 and (b) the relative weight of other causes (nutritional and non-nutritional) of anemia other than iron deficiency can differ between regions. In fact, WHO does not recommend using blood hemoglobin alone as the screening test for iron deficiency 17 . Its low sensitivity is due to the fact that large depletions of body iron reserves are necessary to affect the hemoglobin concentration. Its low specificity is due to the existence of other causes of anemia with high prevalence in certain populations, like other nutritional deficiencies, infections, glucose-6-phosphate dehydrogenase (G6PD) deficiency, and various hemoglobinopathies 19 .

The determinants of iron deficiency in children include maternal anemia, low birth weight, prematurity 26 , parasitic infection 27 , chronic or recurrent infections, short duration of breastfeeding and the introduction of inadequate weaning diets 28 , and the low quality and bioavailability of the iron contained in the diet 29 . The deficiency of other micronutrients not evaluated in this study, like vitamin B12, folic acid, and vitamin A, is another important determinant of nutritional anemia. According to a recent study in the State of Pernambuco with children 6 to 60 months of age, serum vitamin A concentration was one of the factors associated with blood hemoglobin levels 21 .

The low prevalence of helminth infections may be partially explained by periodic deworming with medication, widely distributed by the community health agents in the Family Health Program in both counties. It is unlikely that the fact that a single stool sample was examined greatly underestimated the prevalence of helminth infections with greater clinical impact in the region 30 . The lack of a significant association between helminth infection and anemia or growth deficits in our population (data not shown) is not surprising, given the low prevalence of helminth infections capable of causing significant nutrient depletion, such as Ascaris, Trichuris, and hookworms 27 . However, intestinal protozoan infections were much more prevalent in Acrelândia and Assis Brasil than among under-five children in the municipality of São Paulo who were studied in 1995 and 1996 31, and may contribute to the high prevalence of recent diarrheal disease reported in our sample population (Table 3).

A significant inverse association was observed in Acrelândia and Assis Brasil between household wealth and anemia and malnutrition (but not intestinal parasites). Previous studies also showed an association between socioeconomic conditions and nutritional status in children from various regions of Brazil, both in crosssectional surveys and temporal series analyses. For example, Monteiro et al. 32 observed a lower reduction in the prevalence of child malnutrition in Brazil (from 1975 to 1989) in the lowest per capita income stratum (the poorest $25 \%$ ) as compared to the highest stratum (the wealthiest $25 \%$ ). In the municipality of São Paulo, an increase was observed in the prevalence of anemia in all economic strata among under-five children from 1984 to 1996; however, this trend was more unfavorable among children from the poorest families 22. Studies in Porto Alegre and Criciúma showed similar results in children less than three years of age, with a higher prevalence of anemia in poorer children 23,24 .

Access to clean water and sewage treatment is one of the main determinants of child health and nutrition 33 . The trend in child malnutrition in Brazil from 1975 to 1989 indicates that the observed improvements are associated with increased coverage in sanitation, health, and educational services, as well as in the supply of food supplementation programs. However, the regions with the highest prevalence of child malnutrition in 1975 (the North and Northeast) were the same ones that least benefited from these services and programs, thus increasing the gap between them and the rest of the country 32 . In the two counties of Acre State studied here, the low coverage of basic sanitation poses a serious obstacle to subsequent improvement of child health indicators.

The prevalence of low birth weight in Acrelândia $(9.6 \%)$, resulting from prematurity or intrauterine malnutrition, is within the range found in Latin American countries (6.3-12.5\%) 34 . It is close to the prevalence rates observed in the city of São Paulo in 1998 (8.9\%) 35 and Pelotas, Rio Grande do Sul State, in 2005 (10.4\%) 36. Assis Bra- 
sil showed a low prevalence rate for low weight birth weight (4.5\%), close to that observed in developed countries 34 .

Most mothers in Acrelândia and Assis Brasil initiated breastfeeding, but the median duration of total breastfeeding was low (three months), lower than that reported for the overall Brazilian population (seven months) 37 . However, the prevalence of exclusive breastfeeding up to six months (30\%) was higher than observed by Longo et al. 38 in children using health services in 12 Brazilian State capitals (with an $8 \%$ prevalence of exclusive breastfeeding up to four months of age). Duration of breastfeeding and adequate complementary diet are important upstream determinants of adequate child nutritional status, reducing the risk of malnutrition 39 and iron deficiency anemia 40.

The Millennium Development Goals for developing countries ${ }^{41}$ approved in a special session of the United Nations General Assembly include a reduction by at least one third in the prevalence of malnutrition in under-five children, with a special focus on children less than two years of age, by the year 201542 . The Brazilian National Food and Nutrition Policy also specifies the country's social commitment to reduce the prevalence of iron deficiency ane- mia 43. However a recent UNICEF (United Nations Children's Fund) report 44 shows an extremely unfavorable scenario for Amazonian children, $40 \%$ of whom are from low-income families and $53 \%$ of whom live in communities without adequate basic sanitation, frequently in makeshift housing. The report on the Brazilian health situation entitled Saúde Brasil 2004: Uma Análise da Situação de Saúde 45, estimates the infant mortality rate in the State of Acre at 34.3 per thousand live births in the year 2001, substantially higher than the national average (27.7 per thousand). In 2000 , only $34 \%$ of Acre's population had access to the public water supply, $52 \%$ to garbage collection, and $28.7 \%$ to the public sewage system or septic tanks; all of these indicators are below the national averages. The child development index in Acre is the second worst in the country 46 .

The economic and social disparities between the North/Northeast and Center/South of Brazil indicate the need for adequate implementation of nationwide public policies to minimize the impact of such inequalities on child growth and development. Health diagnoses derived from population-based studies, as that presented here, are fundamental for planning interventions to change this reality. 


\section{Resumo}

As prevalências de desnutrição, parasitoses intestinais, anemia e deficiência de ferro foram avaliadas, por meio de inquéritos transversais de base populacional, em pré-escolares na área urbana de dois municípios das Amazônia Ocidental Brasileira, Assis Brasil ( $n=$ 200) e Acrelândia $(n=477)$. Os índices antropométricos pesolestatura (P/E), peso/idade (P/I) e estatura/idade (E/I) foram calculados como escores $z$, com base na população de referência do National Center for Health Statistics de 1977. Diagnosticaram-se déficits nutricionais segundo indices P/E, P/I e E/I em 3,7\%, 8,7\% e 7,5\% das crianças, respectivamente. Encontraram-se parasitas intestinais em 32,5\% das 554 amostras examinadas, sendo raras as infecções por helmintos. Com base nos níveis de hemoglobina sangüinea e níveis plasmáticos de ferritina e receptor solúvel de transferrina, diagnosticaram-se anemia e deficiência de ferro em $30,6 \%$ e 43,5\% das crianças, respectivamente. Somente $47,6 \%$ das crianças com deficiência de ferro tinham anemia, indicando que a medida isolada de hemoglobina sangüinea subestima a magnitude da deficiência de ferro nesta população. Nos dois municípios, a anemia e a desnutrição foram significantemente mais prevalentes entre as crianças de famílias dos estratos sócio-econômicos mais baixos.

Anemia Ferropriva; Antropometria; Estado Nutricional; Saúde Infantil

\section{References}

1. Victora CG, Barros FC, Kirkwood BR, Vaughan JP. Pneumonia, diarrhea and growth in the first four years of life. A longitudinal study of 5,914 Brazilian infants. Am J Clin Nutr 1990; 52:391-6.

2. Onis M, Monteiro C, Akre J, Glugston G. The worldwide magnitude of protein-energy malnutrition: an overview from the WHO Global Database on Child Growth. Bull World Health Organ 1993; 71:703-12.

3. Onis M, Frongillo EA, Blossner M. Is malnutrition declining? An analysis of changes in levels of child malnutrition since 1980. Bull World Health Organ 2000; 78:1222-33.

4. Food and Agriculture Organization/World Health Organization. International Conference on Nutrition: world declaration and plan of action. Geneva: World Health Organization; 1992.

5. Monteiro CA, Benício MHD. Melhoria em indicadores de saúde associados à pobreza no Brasil dos anos 90: descrição, causas e impacto sobre desigualdades regionais. São Paulo: Núcleo de Pesquisas Epidemiológicas em Nutrição e Saúde, Universidade de São Paulo; 1997.

6 Universidade Federal do Acre/Secretaria Municipal de Saúde de Rio Branco/Fundo das Nações Unidas para a Infância. Diagnóstico das condições de saúde materno-infantil no município de Rio Branco, Acre. Rio Branco: Fundo das Nações Unidas para a Infância; 1994.

\section{Contributors}

P. T. Muniz and M. A. Cardoso designed the research project and obtained funds to implement it. P. T. Muniz coordinated the fieldwork and initial data processing. T. G. Castro participated in the training and supervision of the anthropometry during the fieldwork. T. S. Araújo and N. B. Nunes participated in the supervision of the fieldwork and keying-in and initial processing of the data. M. Da Silva-Nunes, E. H. E. Hoffmann, and M. U. Ferreira processed and analyzed the laboratory samples. T. G. Castro and M. A. Cardoso analyzed the data. T. G. Castro, M. U. Ferreira, and M. A. Cardoso drafted the manuscript, which was read and approved by all the authors.

\section{Acknowledgments}

The authors wish to thank Francisca Souza Santiago for her participation in the fieldwork. T. G. Castro, E. H. E. Hoffmann, and M. Da Silva-Nunes currently receive or have received $\mathrm{PhD}$ scholarships from the São Paulo State Research Foundation (FAPESP), and T. S. Araújo and N. B. Nunes received scientific initiation scholarships from the Brazilian National Research Council (CNPq). This study received funding from the CNPq (grants 502937/2003-3 and 551359/2001-3).

7. Ministério da Saúde. Pesquisa Nacional sobre Demografia e Saúde. http://dtr2004.saude.gov.br/ nutrição/documentos/PesquisaNacDemografia Saude.pdf (accessed on 01/May/2006).

8. Vannucchi H, Freitas MLS, Szarfarc SC. Prevalência de anemias nutricionais no Brasil. Cadernos de Nutrição 1992; 4:7-26.

9. Da Silva-Nunes M, Malafronte RS, Luz BA, Souza EA, Martins LC, Rodrigues SG, et al. The Acre Project: the epidemiology of malaria and arthropodborne virus infections in a rural Amazonian population. Cad Saúde Pública 2006; 22:1325-34.

10. Souza EA, Da Silva-Nunes M, Malafronte RS, Muniz PT, Cardoso MA, Ferreira MU. Prevalence and spatial distribution of intestinal parasitic infections in a rural Amazonian settlement, Acre State, Brazil. Cad Saúde Pública 2007; 23:427-34.

11. Instituto Brasileiro de Geografia e Estatística. Resultados da amostra do censo demográfico 2000. http://www.ibge.gov.br (accessed on 01/ May/2006).

12. Instituto Nacional de Estudos e Pesquisas Educacionais Anísio Teixeira. Mapa do analfabetismo no Brasil. Brasília: Ministério da Educação; 2003.

13. Ministério da Saúde. Atlas de saúde do Brasil [CDROM]. Brasília: Ministério da Saúde; 2004. (Série G. Estatística e Informação em Saúde). 
14. Organización Mundial de la Salud. Medición del cambio del estado nutricional. Genebra: Organización Mundial de la Salud; 1983.

15. Hoffman W, Pons JA, Janer JL. The sedimentation concentration method in schistosomiasis mansoni. PR J Public Health Trop Med 1934; 9:283-91.

16. Chieffi PP, Gryschek RCB, Amato-Neto V. Parasitoses intestinais: diagnóstico e tratamento. São Paulo: Lemos Editorial; 2002.

17. World Health Organization. Iron deficiency anemia: assessment, prevention and control. Geneva: World Health Organization; 2001.

18. Filmer D, Pritchett LH. Estimating wealth effects without expenditure data-or tear: an application to educational enrolments in states of India. Demography 2001; 38:115-32.

19. Cook J. Diagnosis and management of iron-deficiency anaemia. Best Pract Res Clin Haematol 2005; 18:319-32.

20. Oliveira RS, Diniz AS, Benigna MJC, Silva SMM, Lola MM, Gonçalves MC, et al. Magnitude, distribuição espacial e tendência da anemia em pré-escolares da Paraíba. Rev Saúde Pública 2002; 36:26-32.

21. Osório MM, Lira PIC, Ashworth A. Factors associated with $\mathrm{Hb}$ concentration in children aged 6-59 months in the State of Pernambuco, Brazil. Br J Nutr 2004; 91:307-14.

22. Monteiro CA, Szarfac SC, Mondini L. Tendência secular da anemia na infância na cidade de São Paulo (1984-1996). Rev Saúde Pública 2000; 34:62-72.

23. Neuman NA, Tanaka OY, Szarfac SC, Guimarães PRV, Victora CG. Prevalência e fatores de risco para anemia no sul do Brasil. Rev Saúde Pública 2000; 34:56-63.

24. Silva LSM, Giugliani ERJ, Aerts DRGC. Prevalência e determinantes de anemia em crianças de Porto Alegre, RS, Brasil. Rev Saúde Pública 2001; 35:6673.

25. Sari M, Pee S, Martini E, Herman S, Sugiatmi, Bloem MW, et al. Estimating the prevalence of anaemia: a comparison of three methods. Bull World Health Organ 2001; 79:506-11.

26. Rasmussen KM. Is there a causal relationship between iron deficiency or iron-deficiency anemia and weight at birth, length of gestation and perinatal mortality? J Nutr 2001; 131:590S-603S.

27. Stephenson, LS. Impact of helminth infections on human nutrition. New York: Taylor \& Francis; 1987.

28. Davidsson L. Approaches to improve iron bioavailability from complementary foods. J Nutr 2003, 133:1560S-2S.

29. Bhargava A, Bouis HE, Scrimshaw NS. Dietary intakes and socioeconomic factors are associated with the hemoglobin concentration of Bangladeshi women. J Nutr 2001; 131:758-64.

30. Gyorkos TW, McLean JD, Law CG. Absence of significant differences in intestinal parasite estimates after examination of either one or two stool specimens. Am J Epidemiol 1989; 130:976-80.
31. Ferreira MU, Ferreira CS, Monteiro CA. Tendência secular das parasitoses intestinais na infância na cidade de São Paulo (1984-1996). Rev Saúde Pública 2000; 34:73-82.

32. Monteiro CA, Benício MHDA, Iunes RF, Gouveia NC, Cardoso MAA. Evolução da desnutrição infantil. In: Monteiro CA, organizador. Velhos e novos males da saúde no Brasil. 2a Ed. São Paulo: Editora Hucitec; 2000. p. 93-114.

33. Iunes RF. Mudanças no cenário econômico. In: Monteiro CA, organizador. Velhos e novos males da saúde no Brasil. 2a Ed. São Paulo: Editora Hucitec; 2000. p. 33-60.

34. Kramer MS. The epidemiology of adverse pregnancy outcomes: an overview. J Nutr 2003; 133 Suppl 2:1592S-6S.

35. Monteiro CA, Benício MHDA, Ortiz LP. Tendência secular do peso ao nascer na cidade de São Paulo (1976-1998). Rev Saúde Pública 2000; 34:26-40.

36. Barros FC, Victora CG, Barros AJ, Santos IS, Albernaz E, Matijasevich A, et al. The challenge of reducing neonatal mortality in middle-income countries: findings from three Brazilian birth cohorts in 1982, 1993 and 2004. Lancet 2005; 365:847-54.

37. Venancio SI, Monteiro CA. A tendência da prática da amamentação no Brasil nas décadas de 70 e 80 . Rev Bras Epidemiol 1998; 1:40-9.

38. Longo GZ, Souza JMP, Souza SB, Szarfac SC. Crescimento de crianças até 6 meses de idade, segundo categorias de aleitamento materno. Rev Bras Saúde Matern Infant 2005; 5:109-18.

39. Islam MA, Rahman MM, Mahalanabis D. Maternal and socio-economic factors and the risk of severe malnutrition in a child: a case control study. Eur J Clin Nutr 1994; 48:416-24.

40. Lima ACVM, Lira PIC, Romani SAM, Eickmann SH, Piscoya MD, Lima MC. Fatores determinantes dos níveis de hemoglobina em crianças aos 12 meses de vida na Zona da Mata Meridional de Pernambuco. Rev Bras Saúde Matern Infant 2004; 4:35-43.

41. United Nations. UN Millennium Development Goals (MDG). http://un.org./millenniumgoals/ (accessad on 15/Apr/2005).

42. Fundo das Nações Unidas para a Infância. Um mundo para as crianças. http://www.unicef.org/ brazil/wfc.htm (accessed on 15/Apr/2005).

43. Ministério da Saúde. Política Nacional de Alimentação e Nutrição. Brasília: Ministério da Saúde; 2000.

44. Fundo das Nações Unidas para a Infância. Ser criança na Amazônia: uma análise das condições de desenvolvimento infantil na Região Norte do Brasil. 2004. http://unicef.org/brazil/ser_crianca amazonia.pdf (accessed on 15/Apr/2005).

45. Ministério da Saúde. Saúde Brasil 2004: uma análise da situação de saúde. Brasília: Ministério da Saúde; 2004.

46. Fundo das Nações Unidas para a Infância. Situação da infância brasileira 2001. http://www.unicef. org/brazil/sib2001/index.html (accessed on 15/ Apr/2005).

Submitted on 09/Nov/2005

Final version resubmitted on 12/May/2006

Approved on 02/Mar/2007 